\title{
INDEPENDENSI PERADILAN MILITER TERHADAP PRAJURIT TNI SEBAGAI PELAKU TINDAK PIDANA NARKOTIKA
}

\author{
Aulia Jihan Rifani ${ }^{1 *}$, Satria Unggul Wicaksana ${ }^{2}$ \\ ${ }^{1,2}$ Faculty of Law, Muhammadiyah Surabaya University, Indonesia \\ *satria@fh.um-surabaya.ac.id (corresponding)
}

\begin{abstract}
Narcotics can be categorized into extraordinary crimes. Currently, the circulation of narcotics has targeted almost all circles. Military institutions are also not spared from the circulation of narcotics. The basic question is how to handle narcotics crimes by the Military judiciary and the legal efforts that can be made by the soldiers who are accused. The research method used is socio-legal legal studies: Data sources come from secondary data sources or literature studies, which review data from laws and regulations, readings, and books related to research titles. The settlement of narcotics crimes involving TNI soldiers is carried out by the military judiciary. The component or sub-system of military justice is the same as the general judiciary, namely the existence of Ankum and Papera which are important components in the military justice system, in addition to the Military Police, Oditur, and Military Judges. Soldiers involved in such crimes can also make legal efforts as a form of self-defense. The Military Judiciary has the authority to resolve its cases without interference from other agencies, as whose authority and position are contained in Law No. 31 of 1997.
\end{abstract}

Keywords: Narcotics; Military Justice; Legal Efforts; TNI.

\section{PENDAHULUAN}

Narkotika merupakan zat atau obat yang berasal dari tanaman atau bukan tanaman baik sintetis maupun semisintetis, yang dapat menyebabkan penurunan serta perubahan kesadaran, hilangnya rasa, mengurangi sampai menghilangkan rasa nyeri serta dapat menimbulkan ketergantungan yang dapat dibedakan ke dalam beberapa golongan. Seiring berjalannya waktu perkembangan narkotika semakin pesat dan membutuhkan perhatian khusus. Tepatnya pada masa kepemimpinan Orde Baru, pemerintah mengeluarkan regulasi berupa Undang-Undang Nomor 22 Tahun 1997 sebagaimana telah diubah menjadi Undang-Undang Nomor 35 Tahun 2009 Tentang Narkotika (Taufik, 2019).

Narkotika merupakan permasalahan besar yang pemberantasannya menjadi fokus seluruh masyarakat diberbagai kalangan diseluruh dunia. Narkotika termasuk salah satu senjata ampuh untuk melemahkan serta merusak generasi bangsa akibat dahsyatnya dampak yang ditimbulkan. Dalam perkembangannya Narkotika menyasar semua kalangan masyarakat, dan peredarannya bisa melibatkan banyak profesi, mulai dari rakyat kecil hingga para pesohor.

Peredaran narkotika dapat dikatakan pesat, sebab Narkotika sangat mudah didapatkan, kurangnya pengawasan dari pihak yang berwenang, serta keuntungan yang didapat dari penjualannya cukup besar. Penyalahgunaan Narkotika tidak hanya dilakukan oleh kalangan 
pelajar, mahasiswa, masyarakat sipil, maupun pejabat saja namun sudah merambat ke kalangan penegak hukum di Indonesia (Hariyanto, 2018). Salah satunya adalah penyalahgunaan yang dilakukan dikalangan Tentara Nasional Indonesia (TNI).

Pasca terjadinya reformasi pada tahun 1998 muncul desakan dari berbagai pihak untuk melakukan pembenahan di berbagai sektor termasuk diadakannya reformasi dalam sektor militer. Adanya kebijakan politik terkait "Dwi-fungsi" pada Angkatan Bersenjata Republik Indonesia (ABRI) telah menempatkan ABRI dalam ruang penjaga keamanan Negara atas ancaman keamanan serta pertahanan negara. Agenda Reformasi Militer dilakukan melalui dua cara yang diharapkan dapat saling bersinergi (KontraS, 2009).

Agenda tersebut dilakukan melalui Reformasi Institusional yakni dengan melakukan pemisahan fungsi dan peran TNI-POLRI. TNI memiliki fungsi untuk menjaga keamanan dan pertahanan Negara dari ancaman militer dari luar, sedangkan POLRI merupakan institusi sipil yang memiliki fungsi untuk menjaga keamanan didalam negeri. Hal ini ditegaskan melalui TAP MPR NOMOR VI Tahun 2000 Tentang Pemisahan Peran dan Tugas TNI POLRI. Reformasi ini dilakukan guna mewujudkan Profesionalitas, Efisiensi, Efektifitas dan sebagai alat pertahanan yang Demokratis dan Modern (Lisnawati W. Badu).

Penyalahgunaan Narkotika dapat memberikan dampak yang cukup fatal bagi para penggunanya salah satunya dapat menebabkan lemahnya sistim kerja otak bagi para prajurit yang mengkonsumsinya dan dapat menjadikan ancaman baru bagi bangsa. Para prajurit Tentara Nasional Indonesia (TNI) yang terbukti menyalahgunakan Narkotika juga akan ditindak tegas. Seperti yang dilakukan oleh salah seorang prajurit TNI-AD dengan pangkat Sertu di kesatuan Rindam V/Brawijaya, Malang yang terbukti menyalahgunakan Narkotika jenis Sabu, ia dijatuhi hukuman berdasarkan Pasal 127 Ayat (1) huruf a Undang-undang Nomor 35 Tahun 2009 tentang Narkotika Jo Pasal 26 KUHPM Jo Pasal 190 Ayat (2) Undang-undang Nomor 31 Tahun 1997 tentang Peradilan Militer.

Mengingat masih adanya tindak pidana yang terjadi dikalangan Militer yang telah melanggar aturan hukum yang berlaku di Republik Indonesia, mekanisme penyelesaian yang dilakukan pun berbeda dengan rakyat sipil. Para prajurit tersebut akan diadili melalui mekanisme militer dengan tetap memperhatikan undang-undang yang berlaku. Adanya prinsip "Equality Before The Law" seperti yang tertuang dalam Pasal 27 ayat (1) UUD 1945 yang menjadikan acuan bahwa, siapapun yang melakukan suatu tindak pidana akan tetap dijatuhi hukuman, sebab mereka merupakan warga Negara Indonesia yang sepatutnya wajib untuk mentaati aturan-aturan yang sudah berlaku (Lisnawati W. Badu).

Terkait penjelasan permasalahan diatas dapat ditarik dua problema yang akan dibahas pada tulisan ini, 1) Bentuk independensi peradilan militer dalam penanganan perkara tindak pidana Narkotika yang dilakukan oleh anggota militer; 2) Upaya hukum yang dapat ditempuh oleh anggota militer yang terlibat dalam penyalahgunaan Narkotika.

\section{METODE PENELITIAN}

Penelitian kali ini menggunakan metode Sosio-legal. Metode ini merupakan metode yang menghendaki para pengkajinya untuk melakukan kajian atas norma-norma yang ada, baik dalam perundang-undangan maupun putusan pengadilan. Termasuk kajian-kajian atas asas, prinsip, 
doktrin, dan interpretasi yang terkait suatu kasus-kasus atau aturan-aturan (Herlambang P. Wiratraman, 2019).

Bahan yang digunakan menggunakan studi pustaka baik berupa buku, artikel jurnal, serta undang-undang yang berlaku. Sumber data yang digunakan berasal dari sumber data sekunder atau studi kepustakaan, yaitu mengkaji data dari peraturan perundang-undangan, bacaan, dan buku yang terkait judul penelitian.

\section{HASIL DAN PEMBAHASAN}

Peradilan militer merupakan suatu lembaga kekuasaan kehakiman dilingkup militer yang dibentuk untuk menegakkan suatu keadilan dengan tetap memperhatikan unsur pertahanan dan keamanan Negara. Peradilan militer juga merupakan salah satu wujud nyata bagi seluruh masyarakat yakni tetap adanya penegakan hukum meskipun pelanggaran tersebut dilakukan oleh prajurit militer (Rosidah, 2019).

Berlakunya peradilan militer di Indonesia pada tanggal 8 Juni 1946 melalui Undangundang No. 7 Tahun 1946 tentang Peraturan Mengadakan Pengadilan Tentara pada waktu yang sama juga dikeluarkan Undang-undang No. 8 Tahun 1946 yang berisikan tentang Peraturan Hukum Acara Pidana Guna Pengadilan Tentara. Susunan pengadilannya terdiri dari Mahkamah Tentara dan Mahkamah Tentara Agung.

Dalam sistem peradilan militer juga dikenal adanya mekanisme koneksitas yang merupakan aturan untuk mengadili suatu tindak pidana yang dilakukan bersama-sama oleh terdakwa yang termasuk dalam kompetensi peradilan militer dengan terdakwa yang termasuk dalam kompetensi peradilan umum, mengingat kompetensi absolut pengadilan tentara memiliki wewenang untuk mengadili prajurit tentara serta orang-orang sipil yang memiliki keterkaitan dengan kepentingan kemiliteran.

Pada tahun 1948 terjadi perubahan dengan dikeluarkannya PP No. 37 Tahun 1948 jo UU No. 30 Tahun 1948 tentang Pemberian Kekuasaan Penuh Kepada Presiden Dalam Keadaan Bahaya. Peraturan tersebut mengatur tentang perubahan ketentuan susunan, kedudukan serta daerah hukum yang telah diatur. Dalam peraturan ini juga mengatur tentang perluasan kompetensi absolut peradilan militer yakni prajurit TNI, orang yang melalui penetapan presiden ditetapkan setara dengan prajurit TNI, anggota golongan maupun jabatan yang disamakan atau dianggap Tentara oleh Undang-undang ataupun orang yang langsung ditetapkan oleh menteri pertahanan dan mendapat persetujuan menteri kehakiman ,serta terdakwa yang terlibat dalam kejahatan dalam keadaan bahaya berdasarkan pasal 12 UUD 1945.

Susunan pengadilan tentara pada saat itu bertambah lengkap ditandai dengan adanya Mahkamah Tentara, Mahkamah Tentara Tinggi, serta Mahkamah Tentara Agung. Namun hukum acara yang digunakan pada saat itu tetap dan tidak ada perubahan, tetap menggunakan PP No. 38 tahun 1948 dan PP No. 65 Tahun 1948. Pada masa Republik Indonesia Serikat (RIS) pada tahun 1950 peraturan terkait Pengadilan Militer diubah kembali dengan UU Darurat No. 16 Tahun 1950 yang ditetapkan menjadi UU No. 5 Tahun 1950. Pada masa tersebut menggunakan UU Darurat No 16 Tahun 1950 sebagai hukum acara Militer (Dilmiltama, 2013).

Pada undang-undang tersebut juga dijelaskan terkait kekuasaan untuk mengadili terdakwa yang diambil berdasarkan pada kepangkatannya. Terdakwa yang berpangkat Kapten kebawah 
perkaranya dapat diperiksa serta diadili oleh Mahkamah Tentara. Terdakwa yang berpangkat Mayor keatas, diperiksa dan diadili oleh Mahkamah Tentara Tinggi, sedangkan Mahkamah Tentara Agung berwenang untuk memeriksa dan mengadili perkara pada tingkat pertama dan perkara yang yang terdakwanya merupakan pejabat tertentu yang telah ditetapkan oleh undangundang. Mahkamah Tentara Agung juga memiliki kewenangan untuk memutus perselisihan antara sesama Mahkamah Tentara Tinggi serta Mahkamah Tentara yang kedudukannya tidak satu daerah dengan Mahkamah Tentara Tinggi (Nikmah Rosidah, 2019).

Pada tahun 1965 subjek peradilan militer juga bertambah, yakni dengan masuknya Angkatan Kepolisian ditandai dengan dikeluarkannya UU 23/PNPS/1965. Dalam undangundang ini Kepolisian memiliki kewenangan untuk memeriksa serta mengadili suatu perkara terbatas pada tingkat pertama saja. Penyelesaian dalam tingkat banding diperiksa dan diadili oleh Pengadilan Tentara Tinggi dilingkungan angkatan yang ditunjuk langsung oleh Menteri Koordinator Kompartimer Pertahanan Kemanan.

Seiring dengan perkembangannya, Indonesia memiliki Undang-undang khusus yang mengatur tentang Peradilan Militer yaitu UU No 31 Tahun 1997. Dengan dikeluarkanya undangundang tersebut maka undang-undang sebelumnya yang berkaitan dengan Peradilan Militer beserta hukum acaranya UU No 5 Tahun 1950, UU No 6 Tahun 1950, UU Darurat No 1 Tahun 1958, UU No 3 Tahun 1965, UU No 5 PNPS Tahun 1965, serta UU No 23 Tahun 1965 dinyatakan tidak berlaku.

\section{A. Independensi Peradilan Militer}

Dalam penyelesaian suatu tindak pidana tentunya terdapat prosedur-prosedur yang harus dilalui sebelum suatu perkara tersebut diputus. Komponen dalam menyelesaikan suatu tindak pidana dalam peradilan umum terdiri dari Kepolisian yang bertindak untuk melakukan Penyidikan terhadap suatu perkara, Kejaksaan selaku pengacara Negara yang memiliki kewenangan sebagai Penuntut Umum, Pengadilan untuk mengadili suatu perkara, serta Lembaga Permasyarakatan (LP) sebagai tempat untuk melakukan pembinaan terhadap Narapidana berdasarkan UU No. 12 Tahun 1995.

Keempat komponen tersebut menurut Mardjono Reksodiputro, memiliki keterkaitan yang saling berhubungan antara sub-sistem yang satu dengan yang lainnya, keempat komponnen tersebut diharapkan mampu bekerjasama untuk dapat mewujudkan suatu Integrated Criminal Justice Administration (Reksodiputro, 1999). Dalam sistem peradilan militer sama halnya dengan Peradilan Umum yakni adanya komponen atau sub-sistem peradilan. Adanya Ankum dan Papera merupakan komponen yang tidak kalah penting dalam sistem peradilan militer, disamping adanya Polisi Militer, Oditur, serta Hakim Militer.

Suatu kekhususan penyelesaian perkara dalam Militer tidak lain sebab adanya Asas "Unity Of Command" atau "Asas Kesatuan Komando". Hal tersebut memiliki arti bahwa dalam menegakkan hukum di lingkungan Militer peranan Komandan yang bersangkutan tidak dapat dikesampingkan, namun sebagai Negara hukum dalam pelaksanaannya tidak boleh mengabaikan salah satu kepentingan hukum dimana antara asas Unity OF Command (Kesatuan Komando) dengan Asas De Een En Ondeelbaarheid Van Het Parket (Kesatuan Penuntutan) (Utomo, 2018).

Atasan yang berhak menghukum atau biasa disebut Ankum, berdasarkan pasal 1 butir 9 UU No 31 Tahun 1997 merupakan atasan langsung yang memiliki kewenangan untuk menjatuhkan suatu hukuman disiplin menurut ketentuan perundang-undangan yang berlaku dan 
berwenang untuk melakukan penyidikan berdasarkan undang-undang ini. Proses penyidikan merupakan salah satu fungsi mekanisme sistem peradilan pidana, pelaksanaannya-pun diatur didalam KUHAP dan PP No 58 Tahun 2010 tentang perubahan atas PP No 7 Tahun 1983 tentang pelaksanaan KUHAP. Penyidikan berdasarkan Pasal 1 butir 16 UU No 37 Tahun 1997 "Serangkaian tindakan Penyidik Angkatan Bersenjata Republik Indonesia dalam hal dan menurut cara yang diatur dalam Undang-undang ini untuk mencari serta mengumpulkan buktibukti yang dengan bukti ini membuat terang tentang tindak pidana yang terjadi guna menemukan tersangkanya."

Kewenangan Ankum sendiri juga dijelaskan secara rinci didalam Pasal 74, yang berbunyi : a) Melakukan penyidikan terhadap prajurit bawahannya yang ada dibawah wewenang komandonya yang pelaksanaannya dilakukan oleh Penyidik sebagaimana dimaksud dalam pasal 69 ayat (1) huruf b atau huruf c; b) Menerima laporan pelaksanaan penyidikan dari Penyidik sebagaimana dimaksud dalam pasal 69 ayat (1) huruf b atau c; c) Menerima berkas perkara hasil penyidikan dari penyidik sebagaimana dimaksud dalam pasal 69 ayat (1) huruf b atau huruf $c$; dan d) Melakukan penahanan terhadap tersangka anggota bawahannya yang ada dibawah wewenang komandonya.

Berdasarkan hal tersebut kewenangan Ankum dalam pelaksanaan Penyidikan, pelaksanaanya dapat dilakukan oleh Polisi Militer atau Oditur Militer. Ankum memiliki kewenangan yang kuat dalam melakukan pemeriksaan permulaan atas Prajurit Militer yang mejadi anak buahnya dan sebagai pengusut Ankum tidak lagi berkedudukan dibawah Oditur Militer. Dalam pelaksanaan Penyidikan berdasarkan pasal 99 UU No 31 Tahun 1997, baik Polisi Militer maupun Oditur Militer tidak secara mutlak dapat langsung melakukan Penyidikan.

Penyidikan dapat dilakukan apabila penyidik mengetahui, menerima laporan/pengaduan dan telah mendapatkan perintah dari Ankum. Selanjutnya, Penentuan suatu perkara dapat diserahkan ke Pengadilan atau tidak, bukan terletak pada Oditur Militer meski segala persiapan penyelesaian perkara ditangani olehnya. Mengingat sifat penasehat hukum dan Oditur terhadap penyelesaian suatu perkara tidak mengikat, keputusan terhadap penyerahan suatu perkara ke Pengadilan tetap dilakukan oleh Ankum.

Selain Ankum yang memiliki kewenangan besar dalam perkara Militer adalah Perwira Penyerah Perkara atau Papera. Papera berdasarkan pasal 1 butir 10 UU 31 Tahun 1997 merupakan perwira yang berdasarkan undang-undang ini memiliki kewenangan untuk menentukan suatu perkara pidana yang dilakukan oleh Prajurit TNI yang berada dibawah wewenang komandonya akan diserahkan atau diselesaikan diluar pengadilan dalam lingkungan peradilan militer maupun dalam lingkup Peradilan Umum.

Papera juga memiliki kewenangan untuk menutup perkara demi kepentingan hukum atau kepentingan hukum/militer. ${ }^{1}$ Asas tersebut dikenal sebagai asas Oportunitas yang memperjelas besarnya wewenang Papera daripada Oditur. Hal tersebut yang membedakan dengan Praktik Peradilan Umum dimana Asas tersebut hanya dimiliki oleh seorang Jaksa Agung seperti yang tertulis pada Pasal 14 huruf h KUHAP.

Lahirnya lembaga Kepaperaan merupakan salah satu wujud penegakan hukum militer pada tataran normatif, disebabkan adanya keterlibatan kesatuan militer dalam rangkaian penegakan 
hukum khususnya pada rangkaian penyidikan pada prajurit yang terlibat dalam suatu tindak pidana. Dalam rangkaian penyidikan Papera memiliki tugas untuk mengeluarkan surat keputusan penyerahan suatu perkara sebagai syarat kelengkapan berkas perkara serta memasukkan unsur perwira satuan agar dapat duduk dalam majelis hakim (Edy, 2016).

Penyerahan perkara yang dimaksud adalah adanya keputusan tertulis dari Papera untuk menyerahkan perkara pidana yang telah diperiksa dan mendapatkan pendapat dari KUMDAM (Dinas Penasehat Hukum Militer). Apabila terjadi suatu tindak pidana Narkotika yang dilakukan oleh prajurit TNI, yang pertama dilakukan adalah melakukan penyidikan atas laporan masyarakat tersebut. Penyidikan dilakukan oleh Ankum atau dapat memerintahkan Polisi Militer/Oditur untuk melakukan Penyidikan atas aduan tersebut. Selanjutnya apabila sudah ditemukan bukti yang kuat, Prajurit tersebut harus melaksanakan Test Urine guna mendapatkan bukti yang kuat. Setelah terbukti positive hasil tersebut akan diserahkan kepada Oditur guna dibuatkan pendapat hukum untuk penyerahan kepada Papera untuk mendapatkan surat keterangan dan melakukan persidangan (Chandra, 2013).

\begin{tabular}{|c|c|c|}
\hline PROSES & $\begin{array}{c}\text { PENYELESAIAN } \\
\text { NARKOTIKA } \\
\text { PADA SIPIL }\end{array}$ & $\begin{array}{c}\text { PENYELESAIAN NARKOTIKA } \\
\text { PADA PRAJURIT TNI }\end{array}$ \\
\hline PENYIDIKAN & $\begin{array}{l}\text { Pasal } 81 \text { UU No } 35 \text { Tahun } 2009 \\
\text { Tentang narkotika. Dalam } \\
\text { tingkat penyidikan Tindak } \\
\text { Pidana Narkotika yang } \\
\text { dilakukan oleh masyarakat } \\
\text { Sipil diperiksa oleh Penyidik } \\
\text { Kepolisian Republik } \\
\text { Indonesia dan Penyidik } \\
\text { BNN. }\end{array}$ & $\begin{array}{l}\text { Penyidik dan Penyidik Pembantu } \\
\text { Pasal } 69 \text { (1) Undang - Undang } \\
\text { Nomor } 31 \text { Tahun } 1997 \text { Tahun } \\
\text { Tentang Peradilan Militer. } \\
\text { Penyidik adalah: } \\
\text { a.Atasan yang Berhak } \\
\text { Menghukum; } \\
\text { b. Polisi Militer; dan } \\
\text { c. Oditur. }\end{array}$ \\
\hline $\begin{array}{l}\text { PENYERAHAN } \\
\text { PERKARA }\end{array}$ & $\begin{array}{l}\text { Selanjutnya penyidik BNN } \\
\text { Pasal } 80 \text { huruf (a) Penyidik } \\
\text { BNN sebagaimana dimaksud } \\
\text { dalam pasal 75, juga } \\
\text { memiliki kewenangan : } \\
\text { Mengajukan berkas perkara, } \\
\text { tersangka, barang bukti. } \\
\text { Termasuk harta kekayaan } \\
\text { yang disita oleh Jaksa } \\
\text { Penuntut Umum; } \\
\text { memberikan Berita Acara } \\
\text { Pemeriksaan (BAP) dan Alat } \\
\text { bukti yang ditemukan pada } \\
\text { saat penyidikan yang } \\
\text { kemudiandiserahkan kepada } \\
\text { Jaksa Penuntut Umum (JPU) }\end{array}$ & $\begin{array}{l}\text { Pasal } 72 \text { (1) Penyidik membuat } \\
\text { berita acara tentang pelaksanaan } \\
\text { tindakan sebagaimana dimaksud } \\
\text { dalam Pasal } 71 \text { dengan tidak } \\
\text { mengurangi ketentuan lain dalam } \\
\text { Undang-undang ini; (2) Penyidik } \\
\text { sebagaimana dimaksud dalam Pasal } \\
69 \text { ayat (1) huruf b atau huruf c } \\
\text { menyerahkan berkas perkara hasil } \\
\text { penyidikannya kepada Perwira } \\
\text { Penyerah Perkara, Atasan yang } \\
\text { Berhak Menghukum, dan Oditur } \\
\text { sebagai penuntut umum; (3) } \\
\text { Penyerahan berkas perkara kepada } \\
\text { Oditur sebagaimana dimaksud pada } \\
\text { ayat (2) harus disertai penyerahan }\end{array}$ \\
\hline
\end{tabular}




\begin{tabular}{|c|c|c|}
\hline & & $\begin{array}{l}\text { tanggung jawab atas Tersangka dan } \\
\text { barang bukti. }\end{array}$ \\
\hline & $\begin{array}{l}\text { Setelah Jaksa Penuntut } \\
\text { Umum menerima berkas } \\
\text { BAP dan alat bukti } \\
\text { sebgaimana wewenang jaksa } \\
\text { pada Pasal } 14 \text { KUHAP JPU } \\
\text { dapat melakukan } \\
\text { penuntututan di muka } \\
\text { persidangan. }\end{array}$ & $\begin{array}{l}\text { - Pasal } 130 \text { ayat (1)Penyerahan } \\
\text { perkara oleh Perwira Penyerah } \\
\text { Perkara sebagaimana dimaksud } \\
\text { dalam Pasal } 123 \text { ayat (1) huruf f } \\
\text { dilaksanakan oleh Oditur dengan } \\
\text { melimpahkan berkas perkara } \\
\text { kepada Pengadilan yang } \\
\text { berwenang dengan disertai surat } \\
\text { dakwaan. } \\
\text { Sesudah pemeriksaan dinyatakan } \\
\text { selesai, Oditur dapat mengajukan } \\
\text { tuntutan pidana. }\end{array}$ \\
\hline $\begin{array}{l}\text { HUKUMAN \& } \\
\text { PENAHANAN }\end{array}$ & $\begin{array}{l}\text { Setelah dijatuhkannya } \\
\text { Putusan, Tersangka } \\
\text { dilimpahkan ke Lembaga } \\
\text { Permasyarakatan (LAPAS) } \\
\text { guna menjalankan masa } \\
\text { hukuman sesuai yang sudah } \\
\text { diputuskan berdasarkan } \\
\text { Undang-undangyang berlaku } \\
\text { yakni Undang-undang No. } 35 \\
\text { Tahun 2009. }\end{array}$ & $\begin{array}{l}\text { Perkara tersebut dapat segera } \\
\text { disidangkan setelah } \\
\text { mendapatkan perintah dari } \\
\text { Papera. Para prajurit yang sudah } \\
\text { terbukti bersalah dapat } \\
\text { disidangkan dan diberikan } \\
\text { hukuman sesuai dengan undang- } \\
\text { undang yang berlaku terkait } \\
\text { dengan. Penjatuhan pidana dapat } \\
\text { disesuaikan dengan ketentuan } \\
\text { KUHPM. Prajurit yang terlibat } \\
\text { dalam penyalahgunaan } \\
\text { Narkotikajuga dikenai hukuman } \\
\text { tambahan yaitu dengan dipecat } \\
\text { dari kesatuan TNI sesuai dengan } \\
\text { Pasal } 26 \text { KUHPM. }\end{array}$ \\
\hline $\begin{array}{c}\text { HAK } \\
\text { TERSANGKA }\end{array}$ & $\begin{array}{l}\text { Pasal } 81 \text { UU No } 35 \text { Tahun } 2009 \\
\text { Tentang narkotika. Dalam } \\
\text { tingkat penyidikan Tindak } \\
\text { Pidana Narkotika yang } \\
\text { dilakukan oleh masyarakat } \\
\text { Sipil diperiksa oleh Penyidik } \\
\text { Kepolisian Republik } \\
\text { Indonesia dan Penyidik } \\
\text { BNN. }\end{array}$ & $\begin{array}{l}\text { Penyidik dan Penyidik Pembantu } \\
\text { Pasal } 69 \text { (1) Undang - Undang } \\
\text { Nomor } 31 \text { Tahun } 1997 \text { Tahun } \\
\text { Tentang Peradilan Militer. } \\
\text { Penyidik adalah: } \\
\text { a. Atasan yang Berhak } \\
\quad \text { Menghukum; } \\
\text { b. Polisi Militer; dan } \\
\text { c. Oditur. }\end{array}$ \\
\hline
\end{tabular}




\section{B. Pertimbangan Putusan Pada Prajurit Penyalahguna Narkotika}

Narkotika dapat dikategorikan kedalam Extraordinary Crime atau kejahatan luar biasa. Peredaran narkotika dapat dikatakan cukup pesat ia menyasar hampir diseluruh penjuru dunia. Peredarannya cukup gelap bersifat lintas Negara dan teroganisir. Dampak yang ditimbulkan juga tidak main-main, narkoba dapat merusak kesehatan mental, fisik, sosial serta dapat mengancam Pertahanan Keamanan suatu wilayah (Eleanora, 2011).

Narkotika menjadi musuh bagi semua orang di dunia, berbagai cara dilakukan untuk memberantas penyebarannya. Di Indonesia sendiri hukuman mati menanti bagi para pengedar maupun Bandar yang terbukti atas kepemilikan narkotika (Sucoko). Penyalahgunaan narkotika rupanya benar-benar menyasar tidak pandang bulu, siapapun dan dari kalangan manapun dapat terjerat dalam lingkungan barang haram tersebut. Penegakan hukum yang ditegakan dilingkungan Militer harus dilakukan dengan cara yang tegas dengan tetap memperhatikan Asas Kepentingan Militer dan diseimbangkan dengan kepentingan hukum yang berlaku. Dalam mengadili perkara Narkotika maupun pidana non-militer lainnya, hakim militer juga harus tetap memberikan pertimbangan dalam putusannya dengan tidak melihat dari undang-undang saja (Kapten Chk Sator Sapan Bungin).

Seperti yang kita ketahui Narkotika telah berhasil masuk ke wilayah Tentara Nasional Indonesia. Seharusnya ia memiliki kewenangan untuk dapat memberantas peredaran barang haram tersebut namun, justru terlibat didalamnya. Salah satu contoh pada suatu putusan Pengadilan Militer No. 57-K/PM.III-12/AD/II/2018 prajurit tersebut terbukti telah menyalahgunakan Narkotika. Hal ini dibuktikan dengan ditemukannya barang bukti berupa : 1 (satu) set alat penghisap sabu-sabu yang terbuat dari botol the pucuk, 2 (dua) buah sedotan minuman, 1 (satu) buah pipet kaca kecil dan 1 (satu) buah korek api gas, serta 1 (satu) lembar tes hasil laboratorium Narkoba dari Lab. Klinik Pattimura, 1 (satu) lembar Berita Acara Pemeriksaan Urine dari BNN Kota Malang Nomor BA/26/IV/2017/BNNK, 2 (dua) lembar Berita Pemeriksaan Laboratoris Kriminalistik Nomor Lab. 4328/NNF/2017, 1 (satu) lembar foto Barang Bukti botol dan sedotan serta Korek Api yang digunakan untuk mengkonsumsi Sabu dan diperkuat lagi dengan keterangan Saksi 4 yang pernah mengkonsumsi Sabu bersama.

Berdasarkan pada adanya alat bukti dan keterangan dari beberapa saksi yang telah menjalani pemeriksaan terdakwa dapat dijerat dengan pasal 127 ayat (1) huruf a Undang-undang Nomor 35 Tahun 2009 "Setiap Penyalahguna Narkotika golongan I bagi diri sendiri" selain dijerat dengan pasal tersebut terdakwa juga dijerat Pasal 26 KUHPM "Pemecatan dari dinas Militer dengan atau tanpa pencabutan hak untuk memasuki Angkatan Bersenjata. Pidana tambahan dapat dijatuhkan oleh Hakim bersamaan dengan putusan penjatuhan pidana pokok kepada seorang militer yang berdasarkan kejahatan yang dilakukan dipandang tidak layak untuk tetap dalam Militer."

Dalam memberikan putusan tersebut hakim Militer juga memiliki pertimbangan. Pertimbangan yang pertama, perbuatan tersebut jelas telah melanggar hukum yang sudah ditetapkan. Mengingat juga dampak yang dihasilkan oleh penggunaan Narkotika dapat merusak kesehatan dan menjadi ancaman terhadap keamanan dan ketertiban. Kedua, perbuatan yang dilakukan tidak mendukung upaya pemerintah RI untuk melakukan pemberantasan Narkotika. Ketiga, Terdakwa merupakan salah satu Prajurit TNI yang notabene merupakan suatu alat pertahanan Negara yang seharusnya dapat membantu dalam pemberantasan Narkotika. 
Panglima TNI secara tegas juga menerangkan apabila ada prajurit TNI yang terbukti terlibat dalam Penyalahgunaan Narkotika mendapatkan sanksi agar dipecat dari dinas Militer. (Kapten Chk Sator Sapan Bungin) Mengingat dalam menjalankan tugasnya Prajurit TNI dituntut untuk melaksanakan tugasnya secara professional. Namun apabila Prajurit tersebut telah menggunakan Narkotika maka kesehatan Jasmani dan Rohaninya tentu akan terganggu, hak tersebut dapat menggoyahkan stabilitas bangsa dan Negara. Oleh karena itu pemerintah menyatakan harus adanya peperangan untuk memberantas peredaran Narkotika di Indonesia tanpa melihat siapa dan dari kalangan mana pelakunya.

Pemberian hukuman disiplin berupa pencopotannya dari kesatuan TNI murni bersifat kemiliteran dan sekaligus menjadi hukuman pemberat bagi Anggota Militer yang terlibat dalam penyalahgunaan Narkotika. (Riky Pribadi, 2021).

\section{Upaya Hukum Bagi Prajurit}

Prajurit yang terlibat dalam suatu tindak Pidana, memiliki hak yang sama dengan Terdakwa pada umumnya. Para Prajurit mendapatkan hak untuk didampingi oleh Penasehat Hukum dalam penyelesaian perkaranya namun harus atas izin dari Papera atau pejabat yang telah ditunjuk. (KontraS, 2009) Sebagaimana tertulis dalam Pasal 28D ayat (1) UUD 1945 yang berbunyi "Setiap orang berhak atas Pengakuan, Jaminan, Perlindungan dan Kepastian Hukum yang Adil serta perlakuan yang sama dimata hukum." Yang diatur juga didalam pasal 215 UU No 31 Tahun 1997:

(1) Untuk kepentingan pembelaan perkaranya, Tersangka atau Terdakwa berhak mendapat bantuan hukum di semua tingkat pemeriksaan;

(2) Bantuan hukum sebagaimana dimaksud pada ayat (1) diutamakan dari dinas bantuan hukum yang ada di lingkungan Angkatan Bersenjata;

(3) Tata cara pemberian bantuan hukum sebagaimana dimaksud pada ayat (1) diatur lebih lanjut dengan Keputusan Panglima.

Selanjutnya, terkait upaya hukum pada putusan Tingkat Pertama baik Terdakwa maupun Oditur berhak mengajukan Banding Kecuali pada putusan tersebut terbukti bebas dari segala dakwaan dan segala tuntutan hukum yang berkaitan. Oditur maupun terdakwa berhak mengajukan Banding dalam jangka waktu 7 (tujuh) hari sejak putusan pertama dijatuhkan. Panitera tidak diperkenankan menerima Banding apabila telah melebihi batas waktu yang sudah ditentukan serta apabila terjadi penolakan pengajuan Banding Panitera wajib mencantumkan akta penolakan permohonan Banding yang sudah ditandatangani olehnya dan Pemohon yang bersangkutan (Oditur/Terdakwa) (Rosidah, 2019).

Seperti dalam salah satu perkara, pada Putusan No. 57-K/PM.III-12/AD/II/2018 terdakwa telah mendapatkan hak-hak yang memang seharusnya diterima olehnya, yakni didampingi oleh Penasihat Hukum selama perkara tersebut berlangsung serta pengajuan Banding yang secara Formal telah diajukan oleh Terdakwa Sertu. Eko Sudianto Kurniawan dalam Nota Banding yang diajukan Pemohon, pemohon mengajukan Banding agar Pemohon setelah menjalankan hukuman kurungan 1 tahun dapat kembali lagi kepada kesatuan TNI-AD. Namun permohonan tersebut ditolak oleh Majelis Hakim dengan Pertimbangan sebab kesalahan yang dilakukan oleh Pemohon telah mencoreng kesatuan TNI dan bertentangan dengan Sapta Marga TNI.

Namun, apabila dalam jangka waktu tersebut baik Oditur atau Terdakwa maupun Kuasanya tidak mengajukan permohonan Banding maka keduanya dianggap telah menyetujui dan 
menerima hasil putusan pengadilan atas perkara tersebut. Kemudian Panitera berhak mencatat dan membuat akta putusan dan melampirkan pada berkas perkara. Pemeriksaan dalam tingkat Banding dapat dilakukan atas dasar Berkas Perkara dari Pengadilan Tingkat Pertama yang terdiri dari BAP Penyidik.

Setelah suatu perkara diputuskan maka status terdakwa tersebut berubah menjadi Terpidana, berdasarkan UU No. 31 Tahun 1997 terpidana yang dalam putusannya masih berstatus Prajurit TNI maka Oditur berkewenangan melaporkan kepada ANKUM dengan melampirkan Putusan yang sudah berkekuatan hukum tetap (inkracht). Setelah terpidana tersebut menyelesaikan hukuman sesuai dengan keputusan Hakim, ia juga akan menjalani Sanksi Administratif dari tempat ia bernaung (Nico Oviten \& Aprilianda, 2013).

\section{KESIMPULAN}

Narkotika dapat dikategorikan kedalam Extraordinary Crime atau kejahatan luar biasa. Peredaran narkotika dapat dikatakan cukup pesat ia menyasar hampir diseluruh penjuru dunia. Peredarannya cukup gelap bersifat lintas Negara dan teroganisir. Dampak yang ditimbulkan juga tidak main-main, narkoba dapat merusak kesehatan mental, fisik, sosial serta dapat mengancam Pertahanan Keamanan suatu wilayah.

Independensi Peradilan Militer di Indonesia dalam penanganan kasus Narkotika dapat dibuktikan dari dimulainya Penyidikan yang dilakukan oleh Ankum atau dapat dijalankan oleh Polisi Militer dan Oditur atas perintah dari Ankum selaku atasan terdakwa yang memiliki kewenangan untuk melakukan tindakan penyidikan. Selanjutnya, adanya Papera yang berhak memberikan surat keterangan terkait lanjutan proses Peradilan suatu Prajurit. Adanya lembagalembaga yang berwenang menyelesaikan perkara tersebut diatur didalam Undang-undang Nomor 31 Tahun 1997.

Dalam menangani perkara Narkotika, peradilan Militer memberikan sanksi yang tegas bagi Prajurit-prajurit yang terbukti menyalahgunakan Narkotika. Adapun pembuktiannya dapat berupa adanya barang bukti yang ditemukan saat dilakukan penggeledahan, hasil test laboratorium yang menerangkan bahwa prajurit tersebut terbukti mengkonsumsi Narkotika, serta dari keterangan para Saksi. Prajurit yang melanggar ketentuan tersebut dapat dijatuhi pidana sebagaimana Undang-undang yang berlaku, UU No. 35 Tahun 2009 Tentang Narkotika dan Hukuman Tambahan dari Dinas Militer yakni dipecat dari Kesatuan TNI-AD.

Penyalahgunaan Narkotika dalam lingkup Militer merupakan kesalahan yang cukup fatal sebab dampak yang dihasilkan oleh penggunaan Narkotika dapat merusak kesehatan dan menjadi ancaman terhadap keamanan dan ketertiban. Kedua, perbuatan yang dilakukan tidak mendukung upaya pemerintah RI untuk melakukan pemberantasan Narkotika. Ketiga, Terdakwa merupakan salah satu Prajurit TNI yang notabene merupakan suatu alat pertahanan Negara yang seharusnya dapat membantu dalam pemberantasan Narkotika. Bagi para Prajurit yang telah terbukti melakukan Tindak Pidana tetap memiliki hak dan kewenangan seperti tahanan pada umumnya. Para Prajurit juga berhak untuk didampingi oleh Penasihat Hukum selama menjalani masa hukuman. Pemilihan Penasihat Hukum tersebut tetap atas Izin dari Papera. Baik Terdakwa maupun Oditur juga berhak mengajukan permohonan Banding Kecuali pada putusan tersebut terbukti bebas dari segala dakwaan dan segala tuntutan hukum yang berkaitan. 
Penegakan hukum di Indonesia memang seharusnya dilakukan tanpa pandang bulu. Dalam lingkup Peradilan Militer memang sudah seharusnya seluruh Prajurit yang terbukti melakukan suatu Tindak Pidana baik Umum maupun Tindak Pidana Militer seharusnya mendapatkan hukuman yang sesuai dengan Undang-undang yang berlaku di Republik Indonesia. Independensi peradilan Militer memang sudah seharusnya diterapkan mulai dari tingkat Penyidikan sampai Eksekusi Hukuman.

\section{REFERENSI}

Chandra, F. A. (2013, Oktober 28). Penyidikan Tindak Pidana Narkotika Dalam Lingkup Peradilan Militer. Retrieved april 26, 2021, from https://media.neliti.com/media/publications/34840-EN-penyidikan-tindak-pidananarkotika-dalam-lingkup-peradilan-militer-studi-terhada.pdf

Dilmiltama. (2013, June 12). Sejarah Peradilan Militer Dilmiltama. Retrieved May 30, 2021, from Sejarah Peradilan Militer Dilmiltama: https://www.dilmiltama.go.id/home/index.php/tentang-pengadilan/profilepengadilan/sejarah-pengadilan-militer.html

Edy, S. S. (2016). Independensi Sistem Peradilan Militer di Indonesia. Universitas Gadjah Mada. Eleanora, F. N. (2011). Bahaya Penyalahgunaan Narkoba Serta Usaha Pencegahan Dan Penanggulangannya. Jurnal Hukum Unissula.

Hariyanto, B. P. (2018). Pencegahan Dan Pemberantasan Peredaran Narkoba Di Indonesia. Jurnal Daulat Hukum .

Helmi, M. I. (2013). Penerapan Azas "Equality Before The Law" Dalam Sistem Peradilan Militer. Jurnal Cita Hukum.

Herlambang P. Wiratraman, W. D. (2019). Tantangan Metode Penelitian Interdisipliner dalam Pendidikan Hukum Indonesia. MIMBAR HUKUM, 6.

Kapten Chk Sator Sapan Bungin, S. (n.d.). Kepentingan Militer Dalam Proses Hukum Penyalahgunaan Narkotika. Retrieved April 22, 2021, from Dilmiltama: https://www.dilmiltama.go.id/home/ejournal/Kepentinganmiliterdalamproseshukum.pdf

KontraS. (2009). Menerobos Jalan Buntu (Kajian Terhadap Sistem Peradilan Militer Indonesia). Jakarta: KontraS.

Krismen, Y. (2014). Dilema Penegakan Hukum Pidana Terhadap Prajurit TNI. Jurnal Selat, 09. Lisnawati W. Badu, A. (n.d.). Menggagas Tindak Pidana Militer Sebagai Kompetensi Absolut Peradilan Militer Dalam Perkara Pidana. Jurnal Legalitas, 59.

Martono, A. (2012). http://eprints.ums.ac.id/20111/12/10._NASKAH_PUBLIKASI.pdf. Retrieved MAY 21, 2021, from http://eprints.ums.ac.id/20111/12/10._NASKAH_PUBLIKASI.pdf

Nico Oviten, P. D., \& Aprilianda, N. (2013). Kedudukan Hukum Surat Keringanan Pidana Oleh ANKUM Dalam Peradilan Militer. Jurnal Hukum UB.

Nikmah Rosidah, S. (2019). Hukum Peradilan Militer. In Hukum Peradilan Militer (p. 20). Bandar Lampung: AURA.

Reksodiputro, M. (1999). Hak Asasi Manusia Dalam Sistem Peradilan Pidana. Jakarta: Cet. III. 
Riky Pribadi, D. R. (2021). Implementasipenegakan Hukum Pidana Terhadap Oknum Tni Yang Memfasilitasi Pelaku Tindak Pidana Narkotika Berdasarkan Undang-Undang Nomor31 Tahun 1997 Tentang Peradilan Militer. Presumption Of Law Fakultas Hukum Majalengka.

Rosidah, N. (2019). Hukum Peradilan Militer. Bandar Lampung: AURA.

Sucoko, G. H. (n.d.). Retrieved May 24, 2021, from https://media.neliti.com/media/publications/209538-strategi-pencegahanpemberantasan-dan-re.pdf

Taufik, F. Z. (2019). Peran seksi Pencegahan dan Pemberdayaan Masyarakat (P2M) BNNK Ciamis dalam menanggulangi penyalahgunaan Narkotika di wilayah hukum Kabupaten Ciamis. Retrieved 08 11, 2021, from http://digilib.uinsgd.ac.id/22405/: http://digilib.uinsgd.ac.id/22405/4/4_bab\%201.pdf

Utomo, E. (2018). Kewenangan Atasan Yang Berhak Menghukum (ANKUM) Sebagai Penyidik Dalam Sistem Peradilan Militer. Al' Adl Jurnal Hukum. 